\title{
THE REFLECTIONS OF SMARTPHONE USE AND RECREATIONAL USE OF INTERNET BY HIGH SCHOOL STUDENTS TO LEISURE BOREDOM AND ACADEMIC ACHIEVEMENT
}

\author{
Beyza Merve Akgüli \\ Gazi University, Sport Sciences Faculty, \\ Recreation Department, Ankara, Turkey
}

\begin{abstract}
:
The purpose of this study is to evaluate the relationship between, on the one hand, smartphone and recreational internet use, and on the other hand, students' academic success, life satisfaction and boredom in leisure time. The study sample contains 439 randomly selected high school students in Cankaya District, Ankara, Turkey. The questionnaire used to collect data is composed of five parts. These are the "Personal Information Form", "Smartphone addiction scale", "Addiction Profile Index Internet Scan Form (BAPINT)", "leisure boredom scale" and "life satisfaction scale". Frequency and percentage calculations, Pearson Correlations, multiple regression analysis and One-Way ANOVA test were utilized in the analysis. Consequently, it is observed that there is no meaningful difference between students' perceived academic success levels in terms of their smartphone use, $\mathrm{F}(4,434)=2.32, \mathrm{p}>0.05$. However, it is determined that there is a meaningful difference between students' perceived academic success levels with regard to their recreational internet use, $F(4,434)=5.36, p<0.05$. Scheffe test results reveal that students with 'bad' level of perceived academic success have higher recreational internet use than students with 'good' level of perceived academic success. It is observed that there is a positive, medium-level relationship $(r=0.40, p<0.01)$ between high school students' smartphone use and their use of internet for recreational purposes. While it is also observed that there is a positive, medium-level relationship $(\mathrm{r}=0.39, \mathrm{p}<0.01)$ between high school students' level of boredom in leisure time and their smartphone use; it is also found out that the relationship between students' level of boredom and recreational internet use is positive but weak. While it is seen that there is a negative and weak relationship $(\mathrm{r}=-0.16, \mathrm{p}<0.01)$ between students' life satisfaction
\end{abstract}

\footnotetext{
i Correspondence: email beyzakgulgazi@gmail.com 
levels and recreational internet use; it is also determined that relationship between students' life satisfaction levels and smartphone use is negative and weak in a similar fashion $(\mathrm{r}=-0.20, \mathrm{p}<0.01)$. Students' recreational internet use, together with boredom in leisure time, shows a medium level and meaningful relationship with students' smartphone use, $r=0.49, \mathrm{R} 2=0.24, \mathrm{p}<0.01$. These variables, together, account for $24 \%$ of the total variance in smartphone use. In conclusion, it can be stated that recreational use of internet affects students' academic success negatively. Besides, we can say that as level of boredom experienced by students in leisure time increases, so does addiction to smartphone and use of internet for recreation purposes. In turn, high level of smartphone and internet use negatively affects students' life satisfaction levels.

Keywords: smartphone addiction, recreational use of internet, leisure boredom, academic achievement

\section{Introduction}

Leisure time awareness is generally well established in developing and even underdeveloped countries. The problem is not in finding time for leisure time but in using it. Then, what matters is not only being occupied during leisure time; but what one is occupied with. Leisure time carries economic, social, and political value and because of this, it is of interest to large businesses, social health, social engineering, social connectedness, employment, and politics - because of similar reasons, as a consumption tool. Leisure time policies of countries are important in terms of individual and social health. Making good use of leisure time, while also looking after individual and social benefits, is generally the essential objective of leisure time policies. Easy access of people to sports, arts, hobbies and similar activities, provision of adequate services, development of participation incentives are considered important. When leisure time in societies excludes scientific and serious efforts, i.e. nonrecreational activities, the ratio of individuals that are inclined towards "atypical" behaviors increases, because the entire leisure time cannot be spent for recreational activities. Atypical behaviors include drug use, gambling, excessive use of alcohol, and other deviant behaviors, which take place during leisure time.

From this perspective, leisure time resembles a "double edged sword" (Karaküçük,2008). One side of the sword represents values that emerge at an individual and social benefit scale during leisure time, while the other side represents drug use, gambling, and similar activities that are important sources of personal and social problems and are generally not socially acceptable in all countries in the world. 
Making an analogy to the sharp edges of the sword, the effect of such activities that develop on two directions, on individuals and especially on the society can be explained as being also many sided or severe. The value of leisure increases as long as it serves to develop human values and it is not abused for activities that dehumanize people. In a way, the role of leisure time is to regain people the integrity they lost, through sports, arts, tourism, and many other activities; make them happy, make them improve, and provide a basis for new life-styles. In addition, leisure time also allows people to become free from traditional roles and responsibilities imposed by the society and attain a function to return to the renewed consciousness of their existence. This allows people to feel lighter, livelier, and more sensible. However, it should also not be forgotten that the usage of leisure time is not only related to the individual himself, but also to the social, cultural, economic features of the society. Certain values are created as a result of good or bad usage of leisure time. When leisure time is used appropriately and worthily, it allows the individuals to rest; entertain; improve; become creative; associate; increase academic success; socialize; mature; improve views, area of thoughts, and knowledge; carry their own responsibilities; live freely; make choices based on their own desires in using their time, doing work, and studying and thus allows individuals to find themselves. When used improperly, it results in the acquirement of behaviors such as bad habits; calmness; looseness; laziness; carelessness; selfishness; lack of discipline; vagrancy; lack of ideas, views, and emotions; boredom; displeasure; weariness; nervousness, etc(Gill \& Bedini, 2010; Keller, Fleury, \& Rogers, 2010; Dupuis, 2008).

Bad usage of leisure time brings along various physical and behavioral addictions. Among these, Internet and smartphone addictions are one of the most difficult addictions to control especially in adolescents. Addiction, which expresses a specific condition, can be defined as not being able to stop or control a behavior or the use of a substance (Egger and Rauterberg, 1996). Addictions that are not related to a physical substance can be classified as behavioral addictions (e.g. eating, gaming, computer, television, shopping, and Internet addiction) (Kim and Kim, 2002).

According to Davis (2001) "a healthy use of Internet" can be defined as the use of Internet to reach a desired goal, within a suitable time frame, without feeling any intellectual or behavioral discomfort. Problematic usage of internet, on the other hand, is the creation of problems by Internet use in the psychological, social, and cognitive areas of the individual. There is a linear relationship between the duration of staying in front of the computer and eating habits, low physical activity, and increase in obesity. Similarly, it was stated that there is a linear relationship between problematic usage of Internet and depression, social isolation, loneliness, and/or decline in 
home/school/work performance. Another important measure in terms of Internet usage is the intended internet use. The addicting effect of the Internet increases when it is used for online social activities such as meeting new people, talking with individuals with similar interests, and chatting (Ceyhan, 2007; Siyez and Uz Baş, 2013). Official diagnostic criteria for smartphone addiction do not exist. However based on the definition of Internet addiction, smartphone addiction has been defined as the overuse of smartphones to the extent that it disturbs the users' daily lives. It has been reported that smartphone addiction has many characteristics of addiction such as tolerance, withdrawal symptoms, preoccupation, mood deregulation, craving and loss of control5. Smartphone addiction shows similarities to Internet addiction in many respects. Yet, there are also some differences such as the easy portability, real-time Internet access and easy and direct communication features of smartphones.

In other words, it can be seen that the Internet has started to change the social structure. One element is our habits during our leisure time. In our day, people spend an important part of their leisure times on the computer or playing games with their smartphones or surfing in the Internet (Ögel, 2012). The time spent on the Internet in this way can be regarded as using leisure time passively.

Intel has carried out the "Young Turkey Research" with 3,000 young people aged 13-29 in 29 provinces. According to this research, 8.3 percent of young people in Turkey go on the Internet when they get up in the morning even before they go to the bathroom. Again, according to the same research, 4.7 percent of the participants claim that they go on the Internet before they get out of bed and 1 in 4 go on the internet before they leave home. 228 out of 330 minutes of the time spent by young people on computer is spent on the Internet. When we think about the time that is left for the rest of the day, we can see that the time they actively spend outdoors is very little. In the "Social Media and Youth" research made in 26 provinces with 2 thousand and 57 participants and with the support of the Ministry of Youth and Sports, it was determined that one out of every 3 young people spend at least 3 hours of their day in social media.

According to the TSI Information Technologies Household Usage Research (2015), computer and Internet usage rates of individuals aged between 16- 74 were $54.8 \%$ and $55.9 \%$, respectively in April, 2015. These ratios are $64 \%$ and $65.8 \%$, respectively for men and $45.6 \%$ and $46.1 \%$, respectively for women. Computer and Internet usage rates were $53.5 \%$ and $53.8 \%$, respectively in 2014. In April 2015, 96.8\% of the households had either mobile phones or smartphones, while the ratio of fixed phones was $29.6 \%$. During the same period, $25.2 \%$ of the households had desktop computers, $43.2 \%$ had mobile computers, and $20.9 \%$ had a TV that could connect to the 
Internet. When the Internet usage purposes are examined, it can be seen that during the first quarter of $2015,80.9 \%$ of individuals used the Internet to create a profile on social media, send messages or share pictures or other content; $70.2 \%$ to read online news, newspapers or journals; $66.3 \%$ to search for medical information; $62.1 \%$ to upload the texts, images, pictures, videos, music etc. they have created, to websites and $59.4 \%$ to search for information on goods and services. In the first quarter of 2015, $87.1 \%$ of the individuals from age group 16-74 used the Internet at home. This was followed by $42.5 \%$ usage at work; $37.7 \%$ usage at homes of relatives and friends; $29.2 \%$ usage in shopping centers, airports, and other places with wireless connection and $10.6 \%$ usage in Internet cafes. While $74.4 \%$ of the individuals who used the Internet in the first quarter of 2015 used mobile phones or smartphones to connect wirelessly out of home and office, $28.9 \%$ used mobile computers (laptops, notebooks, tablets, etc.). These ratios were $58 \%$ and $28.5 \%$, respectively for the same period of 2014 . Among Internet users who used the Internet within the last 3 months, the rate of regular Internet users who used the Internet almost every day or at least once per week was $94.2 \%$ in the first quarter of 2015.

\section{Adolescence, smartphone usage, life quality}

Adolescence is the period during which children transition to maturity. During this period, children enter a stage of rapid development. Hormonal changes take place in their bodies during this period. They begin to acquire physical properties that will allow them become young mothers or fathers. In addition, adolescents experience changes in emotional, social, and cognitive areas. During this period, adolescents become more drawn to friend groups and are much prone to peer influence. In this period, an increase in risky behaviors is observed. As a result of these changes, identities are shaped leading to the development of an adult (Guerra, Williamson and Lucas-Molina, 2015).

Urbanization has deprived youngsters of their playgrounds. Streets are being invaded by vehicles. Buildings have been constructed in every available space in the city and areas where youngsters can play freely have been reduced. Schoolyards are being kept closed out of school hours for security reasons. Youngsters whose playground areas have been reduced prefer more passive activities. Another issue that has to be emphasized as well is the increase of device displays that children can reach in their environment. Adolescents have been exposed only to television in the past and now are exposed to a multitude of device displays including tablets, smartphones, 
computers, and television. The spread of Internet and the increase of device displays at home direct the interest of adolescents to these.

Smartphones are popular technological devices, that are capable of processing more information than other mobile phones and include many features such as Internet access, multimedia, and navigation in addition to communication use. The primary difference between plain mobile phones and smartphones is that smartphones provide easy access to the Internet and various applications that can be downloaded. Because of these properties, they are becoming widespread among adolescents. On the other hand, since their playgrounds are reduced, adolescents have resorted to meet their playing needs in the virtual platform. However, virtual games cannot provide the benefits of outdoor games. In their research, Arslan et al. (2010) determined that the traditional play culture and physical activity habits of primary and secondary education students underwent a change and that these gave way to computer games over time (Arslan, Yücel and Güllü, 2010, p. 28). As a result, problems such as Internet and technology addiction have arisen. The spending of adolescents excessive time with devices and the inclination towards games with violent content have become major concerns for many families.

In a study conducted in South Korea in 2012, the frequency of smartphone addiction $(8.4 \%)$ was observed to be higher than the frequency of Internet addiction (7.7\%). The same study reported that $11.4 \%$ of $10-20$ year-old individuals and $10.4 \%$ of 20-30 year-old individuals suffered from smartphone addiction. It has been argued that especially the Internet gaming and social networking features of smartphones are increasingly becoming a problem. The percentage of users of smartphones is rapidly increasing in the Turkish population. In a 2013 study, the smartphone use rate was found to be $19 \%$ in Turkey. This rapid increase brings about addiction and problematic usage of smartphones.

All this body of research shows that the ratio of Internet and smartphone use for recreational purposes is especially high among adolescents and is one of the subjects on which up-to-date studies are required.

\section{Purpose of the Study}

The purpose of this study is to evaluate the relationship between the status of smartphone use and recreational Internet use by high school students and their academic success rates, life satisfaction and leisure boredom levels.

H1: There is a positive relationship between leisure boredom and smartphone and recreational Internet use. 
H2: The academic success level of high school students varies according to their status of smartphone and recreational Internet use.

H3: Recreational Internet use and leisure boredom, together, significantly predict smartphone use by high school students.

H4: There is a negative relationship between life satisfaction levels of students and smartphone and recreational Internet use.

\section{Method}

\section{Population and Sample}

The population of the research comprises high school students who study at public schools in Çankaya county of Ankara. Based on data collection studies, 501 questionnaires have been applied and the number of applicable and valid questionnaires is 474 . Since based on its purpose, the study targeted smartphone using students, 25 students without smartphones were not included in the study. Therefore, the sample of the study consists of 439 high school students selected from this universal set through random sampling. Different demographic information of students is given in Table 1. Permissions necessary to carry out the study during the fall semester of 20152016 were obtained.

\section{Data Collection Tools}

The questionnaire used to collect data is composed of five parts. These are the "Personal Information Form", "Smartphone addiction scale", "Addiction Profile Index Internet Addiction Form (APIINT)", "leisure boredom scale" and "life satisfaction scale". Demographical questions were asked in the personal information form about gender, age, perceived income, perceived academic success level, perceived leisure time sufficiency, class of education, etc.

Smartphone Addiction Scale-Short Version (SAS-SV): The SAS-SV, which was developed by Kwon et al. to measure the risk of smartphone addiction among adolescents and the Turkish version of which was adapted by Noyan et al. (2015), consists of 10 items and is assessed with a six-point Likert scale. Scale items are scored from 1 to 6. Scale scores range between 10 and 60. As the scores obtained from the test increase, it is assessed that the risk of addiction increases as well. The scale is single factored and does not have subscales. For the Korean sample, the cut-off value was stated as 31 for males and 33 for females. Since no clinical trials were carried out in Turkey, the cut-off value was not determined. The Cronbach's alpha coefficient of SAS$\mathrm{SV}$, which consists of ten items, was determined as 0.867 . 
The Addiction Profile Index Internet Addiction Form: 2 questions were selected to use as a screening form. The combination of the two questions "duration of Internet use" and "Internet use can cause problems in a person's life" shows high correlation with the general (APIINT) score $(0.82, \mathrm{p} \square 0.01)$. In the screening form, the sensitivity at the cutoff point for a score of 3.5 is 0.72 and specificity is 0.83 (PPV: 97.5 NPV:75.7).

Leisure boredom scale: The second section consisted of the Leisure Boredom Scale, and it was used to assess perceptions of boredom in leisure (LBS: Iso-Ahola and Weissinger, 1990). It is a 16 item instrument scored on a 1 to 5 scale; higher numbers indicate higher levels of boredom. It asks people to indicate how they feel about their leisure time (i.e., non-work hours). Iso-Ahola and Weissinger (1990) reported alpha reliability on the total scale ranging from .85 to .88 . LBS was added to Turkish literature in 2014 for high school students after the validity and reliability of the studies were conducted by Siyez and Soylu. It includes two subscales and a total of 12 items. The first subscale is 'perfection' which measures students' leisure time arrangement and management skills. The second subscale is 'motivation' and it measures students' skills in taking leisure time effectively. Overall alpha reliability for the LBS was .87. For this study, the internal consistency coefficient was .85 and the significance level was $\mathrm{p}<.01$. LBS is a five-point Likert-type scale, whose highest point is 12 and lowest point, 80 .

The Satisfaction with Life Scale: To determine participants' levels of life satisfaction, the Satisfaction with Life Scale developed by Diener, Emmons, Larsen and Griffin (1985) and adapted into Turkish language by Durak, Durak et al. (2010) was used. The scale developed by Diener et al. (1985) includes five items. Cronbach's Alpha coefficient of the scale was calculated to be .87 . It was found that the one-factor scale explains $66 \%$ of the variance. The Turkish adaptation of the scale was made by Durak et al. (2010) and in their adaptation; the confirmatory factor analysis showed that it has a one-factor good fit index. Cronbach's Alpha coefficient of the scale in the Turkish adaptation was calculated as .81. For this study, Cronbach's Alpha coefficient value was found to be .77 .

\section{Analysis of data}

Frequency and percentage calculations were made for the demographics of the research group. The distributions of the variables according to the groups were examined, and evaluating the normality of the distributions and the homogeneity of the variances, it was concluded that the distributions did exhibit parametric quality. In order to test whether there was a significant difference between smartphone and recreational Internet use of high school students according to perceived academic success levels, One-Way ANOVA test was applied. When multiple variables were examined, Scheffe test was applied in order to determine which groups had significant differences 
between each other. Pearson Correlation analysis was used to reveal the relations between participants' scores of smartphone addiction, APIINT, leisure boredom and life satisfaction. In addition, multiple regression analysis regarding smartphone use during leisure time was applied. In analysis of the data, the R Project package was used. The significance level for the statistical analyses was accepted as 0.05 .

Table 1: Demographics of the Participants (N=439)

\begin{tabular}{llll}
\hline & & $\mathrm{N}$ & $\%$ \\
\hline Gender & Male & 237 & 54.0 \\
& Female & 202 & 46.0 \\
Perceived Income & Low & 31 & 7 \\
& Moderate & 218 & 49.7 \\
Leisure Time Sufficiency & High & 190 & 43.3 \\
& Very Insufficient & 97 & 22.1 \\
& Insufficient & 154 & 35.1 \\
& Moderate & 106 & 24.1 \\
& Sufficient & 65 & 14.8 \\
Perceived Academic & Very Sufficient & 17 & 3.9 \\
Success Level & Very bad & 11 & 2.5 \\
& Bad & 73 & 16.6 \\
& Normal & 214 & 48.7 \\
& Good & 125 & 28.5 \\
& Very good & 16 & 3.7 \\
\hline
\end{tabular}

\section{Results}

218 of 439 students (49.6\%) are Internet addicts (higher than 3.5 points). As mentioned previously, no cut-off point is available for smartphone use in Turkey. The other results of the study are presented in the order of the research question and corresponding hypothesis. The tables that contain results with statistically significant differences are given below.

H2: The academic success level of high school students varies according to their status of smartphone and recreational Internet use.

Table 2: ANOVA Results of APIINT scores of students based on their perceived academic success levels

\begin{tabular}{|c|c|c|c|c|c|}
\hline & $\begin{array}{l}\text { Perceived Academic } \\
\text { Success Level }\end{array}$ & $\mathrm{N}$ & $\bar{x}$ & $\mathrm{~F}$ & $\mathrm{p}$ \\
\hline Recreational Internet Use & Very Bad & 11 & 4.27 & 5.35 & $.000^{*}$ \\
\hline
\end{tabular}


(APIINT)

$\begin{array}{lll}\text { Bad } & 73 & 4.27 \\ \text { Normal } & 214 & 3.70 \\ \text { Good } & 125 & 3.10 \\ \text { Very Good } & 16 & 3.69\end{array}$

Based on the results of ANOVA, which was applied to test whether there was a significant difference between smartphone use by high school students according to their perceived academic success levels, no significant difference between smartphone use by high school students according to their perceived academic success levels was observed, $\mathrm{F}(4,434)=2.32, \mathrm{p}>0.05$.

However, significant difference was determined between recreational Internet use by high school students according to their perceived academic success level $\mathrm{F}(4,434)=5.36, \mathrm{p}<0.05$. According to the Scheffe test, which was carried out in order to determine which groups had significant differences in academic success levels between each other, it can be seen that the rate of recreational Internet use by students who perceive their academic success level as "bad" is higher than those who perceive their academic success level as "good". In other words, it can be claimed that an excessive recreational use of Internet has a negative influence on the academic success of students. It can be claimed that hypothesis-2- was partially proved.

H1: There is a positive relationship between leisure boredom and smartphone and recreational Internet use.

Table 3: Analysis of the Correlation between Leisure Boredom, Life Satisfaction, Perceived Academic Success, Apiint and Smartphone Usage

\begin{tabular}{|c|c|c|c|c|c|c|}
\hline & & 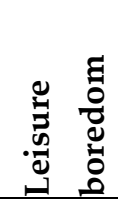 & 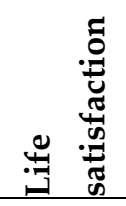 & 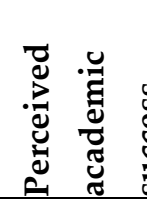 & 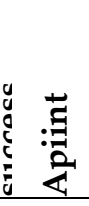 & 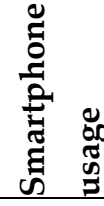 \\
\hline \multirow[t]{3}{*}{ Leisure boredom } & Pearson Correlation & 1 & & & & \\
\hline & Sig. (2-tailed) & & & & & \\
\hline & $\mathrm{N}$ & 439 & & & & \\
\hline \multirow[t]{3}{*}{ Life satisfaction } & Pearson Correlation & $-.100^{*}$ & 1 & & & \\
\hline & Sig. (2-tailed) & .037 & & & & \\
\hline & $\mathrm{N}$ & 439 & 439 & & & \\
\hline \multirow[t]{3}{*}{ Perceived academic success } & Pearson Correlation & -.018 & $.187^{* *}$ & 1 & & \\
\hline & Sig. (2-tailed) & .711 & .000 & & & \\
\hline & $\mathrm{N}$ & 439 & 439 & 439 & & \\
\hline \multirow[t]{3}{*}{ Apiint } & Pearson Correlation & $.111^{*}$ & $-.158^{* *}$ & $-.188^{* *}$ & 1 & \\
\hline & Sig. (2-tailed) & .020 & .001 & .000 & & \\
\hline & $\mathrm{N}$ & 439 & 439 & 439 & 439 & \\
\hline
\end{tabular}


Smartphone usage

$\begin{array}{llllll}\text { Pearson Correlation } & .338^{* *} & -.205^{* *} & -.139^{* *} & .395^{* *} & 1 \\ \text { Sig. (2-tailed) } & .00 & .000 & .004 & .000 & \\ \text { N } & 439 & 439 & 439 & 439 & 439\end{array}$

It can be seen that there is a positive and moderate relationship $(\mathrm{r}=0.40, \mathrm{p}<0.01)$ between smartphone use and recreational Internet use by high school students. According to this, it can be claimed that as the degree of recreational Internet use increases, smartphone addiction increases as well. While it was observed that there was a positive and moderate relationship between leisure boredom and smartphone use $(r=0.39$, $\mathrm{p}<0.01$ ) by high school students, it was determined similarly, that there was a positive and weak relationship between leisure boredom and recreational Internet use by students $(\mathrm{r}=0.11, \mathrm{p}<0.05)$. In other words, as the leisure boredom level of students increased, smartphone addiction and recreational Internet use increased as well. Hypothesis-1- was proved.

H4: There is a negative relationship between life satisfaction levels of students and smartphone and recreational Internet use.

While a negative and weak relationship was observed between life satisfaction levels of students and recreational Internet use $(\mathrm{r}=-0.16, \mathrm{p}<0.01)$, similarly, a negative and weak relationship was determined between the life satisfaction levels of students and smartphone use $(\mathrm{r}=-0.20, \mathrm{p}<0.01)$. In other words, excessive smartphone use and recreational Internet use have a negative influence on life satisfaction levels of students. Hypothesis-4- was proved.

H3: Recreational Internet use and leisure boredom, together, significantly predict smartphone use by high school students

Table 4: Multiple regression analysis regarding smartphone use during leisure time

\begin{tabular}{|c|c|c|c|c|c|c|c|}
\hline Variable & B & Standard Error & $\beta$ & $\mathrm{T}$ & $\mathrm{p}$ & $\begin{array}{l}\text { Binary } \\
\mathrm{r}\end{array}$ & $\begin{array}{l}\text { Partial } \\
\text { r }\end{array}$ \\
\hline Fixed & .882 & 2.880 & - & 0.306 & .760 & - & - \\
\hline Apiint & 2.371 & 0.274 & 0.362 & 8.646 & .000 & 0.395 & 0.360 \\
\hline Leisure boredom & 0.561 & 0.079 & 0.297 & 7.095 & .000 & 0.338 & 0.295 \\
\hline $\mathrm{R}=0.494$ & $\mathrm{R} 2=0.244$ & & & & & & \\
\hline$F(2,438)=70.218$ & $\mathrm{P}=.0000$ & & & & & & \\
\hline
\end{tabular}

According to the multiple linear regression analysis results, the recreational Internet use and leisure boredom of students, together, show a moderate and significant 
relationship with their smartphone use scores, $\mathrm{r}=0.49, \mathrm{R} 2=0.24, \mathrm{p}<0.01$. The aforementioned variables, together, explain $24 \%$ of the variance in smartphone use. Hypothesis-3- was proved.

\section{Discussion}

218 of 439 students (49.6\%) are recreational Internet use addicts (higher than 3.5 points). As mentioned previously, no cut-off point is available for smartphone use in Turkey. Results show that students are gradually drawn away from active recreational life and become inclined to smartphone and recreational Internet use in order to overcome leisure boredom. Such that, according to the TSI 2015 Time Use Survey, the activity for which individuals allocated the least amount of time in Turkey was sports and nature sports, with 11 minutes (individuals aged 10 and above). After sports, activities for which the lowest amount of time was allocated were hobbies and games, with 21 minutes and volunteer work and meetings with 43 points, respectively. Besides this, when the social activities that they were involved in were examined, it was seen that the rate of time spent in social media was 33.9\% and watching TV ranked first with a rate of $94.6 \%$. These results, which actually show parallelism with the adolescent profile in the world, are thought-provoking as they were obtained for a period of life in which adolescents have to gain experience and acquire habits through physical activities.

In addition, these results also support another finding of the study. While a negative and weak relationship was observed between life satisfaction levels of students and recreational Internet use $(r=-0.16, p<0.01)$ in the study, similarly, a negative and weak relationship was determined between the life satisfaction levels of students and smartphone use. In other words, excessive smartphone use and recreational Internet use have a negative influence on life satisfaction levels of students. These findings show that students, actually, experience boredom in their leisure time and don't know exactly how to manage it. Apart from this, recreational activities for adolescents in cities are quite restricted and most of the time, transportation is challenging and deterring.

According to Ozdemir (2009), generally, well-kept and safe parks are located in high-income group neighbourhoods. While on the other hand, parks in regions where low-income groups reside are not maintained well and consist of green areas that are constantly exposed to vandalism. The migration of recreational activity areas to closed and special locations may be directing adolescents towards the easily accessible recreational Internet use and smartphone use. Based on the finding of the study that were explained above, we may claim that these conditions influence adolescents 
negatively and that adolescents are, at one point, forced to recreational Internet and smartphone use. On the other hand, it is clear that Internet use, which has reached a level of addiction, has some harmful effects. Internet addiction leads to emotional, social and sexual function disorders, psychiatric disorders and anxiety (Shapira et al. 2000), introversion (Young 2007), increase in level of depression (Cao, Su, Liu and Gao 2007; Caplan 2002; Kang 2007; Kraut, Paterson, Lundmark, Kiesler, Mukophadhyay and Scherlis 1998; Sang, Whang, Lee and Chang 2003; Shapiro, 1999; Young and Rodgers 1998b). Furthermore, recent studies have indicated that Internet addicts gradually become less interested in social activities (Nie and Erbring 2000; Robin and Cooper 2003; Shapiro 1999), start to exhibit nonfunctional social behaviors (Sang et al. 2003), have narrowing social environments (Kraut et al. 1998), have daily life problems (Chou and Hsiao 2000; Young 2007) and have weakening in-family communications (Kraut et al. 1998; Willoughby 2008). Shortly, Internet addiction might result in social, academic, familial and professional degenerations (Young 2007). However, the inactive more lonely adolescents are more likely to become pathological Internet users (Young and Rodgers 1998a).

One other finding of the study is also consistent with what was mentioned above. It can be seen that there is a positive and moderate relationship $(r=0.40, p<0.01)$ between smartphone use and recreational Internet use by high school students. According to this, it can be claimed that as the degree of recreational Internet use increases, smartphone addiction increases as well. While it was observed that there was a positive and moderate relationship between leisure boredom and smartphone use $(\mathrm{r}=0.39, \mathrm{p}<0.01)$ by high school students, it was determined similarly, that there was a positive and weak relationship between leisure boredom and recreational Internet use by students $(\mathrm{r}=0.11, \mathrm{p}<0.05)$. In other words, as the leisure boredom level of students increased, smartphone addiction and recreational Internet use increased as well. One other finding is also consistent with this. According to the multiple linear regression analysis results, the recreational Internet use and leisure boredom of students, together, show a moderate and significant relationship with their smartphone use scores, $r=0.49$, $\mathrm{R} 2=0.24, \mathrm{p}<0.01$. The aforementioned variables, together, explain $24 \%$ of the variance in smartphone use. Perceptions of leisure as boredom are associated with negative effect, and can be manifested as beliefs that available leisure experiences are not sufficiently frequent, involving, exciting, varied, or novel (Iso-Ahola and Weissinger, 1990). Leisure boredom is related to other forms of addiction and has been implicated in deviant activity involvement, particularly drug use and delinquency (Iso-Ahola \& Crowley, 1991). On the other hand, the smartphone allows adolescents, while having not much to do, to be engaged in a number of activities, such as texting in SMS, gaming, accessing 
the Internet, reading online news, shooting and viewing pictures or video, among others. This is surprising considering that such activities probably occur most often during leisure time and in leisure settings (Leung, 2007). This situation can direct adolescents to use smartphones excessively during their leisure times. In addition to these, it is also observed that as a result of exam stress, adolescents cannot find an opportunity for sports and active recreational activities and they are also not supported by their families. Yet, for a healthy society, adolescents have to be active and regard sports as a part of their life.

Based on the results of ANOVA, which was applied to test whether there was a significant difference between smartphone use by high school students according to their perceived academic success levels, no significant difference between smartphone use by high school students according to their perceived academic success levels was observed, $F(4,434)=2.32, p>0.05$. However, significant difference was determined between recreational Internet use by high school students according to their perceived academic success level $\mathrm{F}(4,434)=5.36, \mathrm{p}<0.05$. In other words, it can be claimed that an excessive recreational use of Internet has a negative influence on the academic success of students. This connection could be interpreted by the lack of sleep and concentration due to Internet use patterns (Kubey, Lavin, \& Barrows, 2001).There are also studies in the literature which support this finding. Internet addiciton has been significantly negatively associated with academic achievement (Yang \& Tung, 2007). Yet, most of these studies are cross-sectional and the causal relation is not clear. Internet addiction has been shown to be both a predictor (Morahan-Martin \& Schumacher, 2000) and an outcome of poor academic achievement (Huang et al., 2009).Similarly, in a study which was carried out to determine the relationship between computer games and the academic success of students, a weak relationship was determined between these. It was noted that, without considering any other factors, computer games were blamed for the poor academic performance of students at school [10]. The Turkish Digital Games Federation has also mentioned the negative effects of recreational Internet use.

According to this, it was claimed that adolescents became asocial as a result of studying, reading, spending less time for activities like sports, and excessive gaming. Allocating too much time for gaming can also affect future academic success negatively. Depending on the game and the game control system, physical problems from obesity to Carpal Tunnel syndrome may arise. In online games, children are prone to online threats and also these may lead to poor language development. It is also possible that some games lead to addiction and the manifestation of tension and stress in children. Facing excessive gaming related attention-deficit problems is also plausible. 
In summary, according to this study, the purpose of which was to assess the relationship between smartphone and recreational Internet use by high school students with their academic success levels, life satisfaction, and leisure boredom levels; a negative and weak relationship was determined between the life satisfaction levels of students and their recreational Internet and smartphone use status. On the other hand, while it was observed that smartphone use increased as the degree of recreational Internet use increased, it was also determined that as leisure boredom of students increased, their smartphone addiction and use Internet for recreational purpose increased as well. It is very important that schools and families realize various projects to prevent this passive form of recreational life that may be considered harmful and may lead to various disorders, but most importantly may become a habit for students. Based on the great interest in computer games in our day, researchers are developing game-based educational designs. Age, gender, and personal characteristics are taken into consideration in the development process of these. Research shows that online games lead to very successful results in education and this success is associated with the entertaining nature of learning through games.

Utilization of urban parks is more a social behavior than an individualistic one and allows the development of the public sphere. In addition, these areas are preferred and increase in value owing to benefits such as health, social communication, psychological relief, improvement of environmental quality, which they provide in the urban environment. Very few people consider parks as misspent urban areas. Making these areas usable and accessible for all people from all sections of the society and from all classes without any gender discrimination is imperative to increase the quality of urban life, public sphere, and environment (Özdemir, 2009). If these parks are designed according to the needs of youngsters, they can become alternative recreational areas for them.

Effective management and allocation of time during after-school hours is especially important for adolescents because they have more time outside the home without parental supervision than do younger children (Stattin, Kerr, Mahoney, Persson, \& Magnus-son, 2005). To determine the effects of out-of-school activities on various social and academic outcomes, researchers have examined patterns of students' out-of-school activities by students' characteristics (Gross, 2004; Pedersen \& Seidman, 2005). South Korea also supports various after-school programs. Korean government began more actively supporting after-school activities and eventually the 5 school days policy spread from the major cities to areas across the nation (Ministry of Education \& Human Resources, 2006). Hofferth and Sandberg (2001) also found that reading for 
pleasure and having active leisure time have positive effects on achievement and cognitive tests.

\section{References}

1. O. Egger, Ö. Rauterberg. Internet behavior and addiction. Unpublished Master's thesis, Swiss Federal Institute of Technology, Zurich, 1996.

2. R. A. Davis. A cognitive-behavioral model of pathological Internet use. Computers in Human Behavior, 17, 187-195. Doi:10.1016/S0747-5632, 2001.

3. D.M. Siyez, A. Uzbaş .İnternet bağımlılığı ve psikososyal faktörler. M. Kalkan ve C. Kaygusuz (Ed.), İnternet bağımlılı̆̆: Sorunlar ve çözümler içinde. Ankara, Anı Yayıncilık, 2013.

4. K. Ögel. İnternet Bağımlılı̆̆ı: İnternetin Psikolojisini Anlamak ve Bağımlılıkla Başa Çıkmak .İstanbul: İş Bankası Kültür Yayınları, 2012.

5. Guerra, G., Williamson A. A., Lucas-Molina, B. (2012). Normal development: Infancy, childhood and adolescence, IACAPAP Textbook of Child and Adolescent Mental Health, Chapter A.2. 1-39.

6. Arslan C., Yücel A. S., Güllü M. (2010). İlköğretim ve Ortaöğretimde Öğrenim Gören Öğrencilerin spor ve oyun alışkanlıklarının incelenmesi. E-journal of New World Sciences Academy. 5(1): 28-46.

7. Kwon M, Kim DJ, Cho H,Yang S. The smartphone addiction scale: development and validation of a short version for adolescents. PloS One 2013; 8:e83558.

8. Noyan C.O, Darçın A.E., Nurmedov S, Yılmaz O., Dilbaz N. (2015). Akıllı Telefon Bağımlılığı Ölçeği'nin Kısa Formunun Üniversite Öğrencilerinde Türkçe Geçerlilik ve Güvenilirlik Çalışması. Anadolu Psikiyatri Derg. 16(Özel sayı 1): 7381.

9. Soylu Y, Siyez DM, (2014) 'Leisure Time Boredom Scale: A Study for Reliability and Vailidity for Turkey'. Ege Education J. 15(1):80-95.

10. Diener, E. D., Emmons, R.A., Larsen, R. J., and Griffin, S. (1985) The satisfaction with life scale. Journal of Personality Assesment, 49(1), 71-75.

11. Özdemir A. (2009). Katılımcı Kentli Kimliğinin Oluşumunda Kamusal Yeşil Alanların Rolü: Ankara Kent Parkları Örneği, Süleyman Demirel Üniversitesi Orman Fakültesi Dergisi, 1, 144-153.

12. Shapira, N.A., Goldsmith, T.D., Keck, P.E., Khosla, U.M. \& McElroy, S.L. (2000). Psychiatric features of individuals with problematic internet use. Journal of Affective Disorders, 57; 267- 272. 
13. Young, K. S. (2007). Treatment outcomes with internet addicts. CyberPsychology \& Behavior, 10(5); 671 -679.

14. Young, K. S. \& Rodgers, R. C. (1998a). Internet addiction: personality traits associated with its development. 69th Annual Meeting of the Eastern Psychological Association.

15. Young, S. K, \& Rodgers, R. C. (1998b). The relationship between depression and internet addiction. CyberPsychology and Behavior, 1(1); 25- 28.

16. Nie, N. \& Erbring, L. (2000). Debating the societal effects of the internet: Connecting with the world. Public Perspective,11; 42- 43.

17. Robin M. M. \& Cooper, A. (2003). The duration and frequency of internet use in a nonclinical sample: Suicidality, behavioral problems, and treatment histories. Psychotherapy: Theory, Research, Practice, Training, 40(1-2); 125-135.

18. Sang, L., Whang, M., Lee, S. \& Chang, G.(2003). Internet over-users' psychological profiles: A behavior sampling analysis on internet addiction. CyberPsychology \& Behavior, 6(2); 143- 150.

19. Kraut, R., Paterson, M., Lundmark, V., Kiesler, S., Mukophadhyay, T. \& Scherlis, W. (1998). Internet paradox: A social technology that reduces social involvement and psychological well-being? American Psychologist, 53 (9) ; 1017-1031.

20. Chou, C. \& Hsiao, M.C. (2000). Internet addiction, usage, gratification and pleasure experience: the Taiwan college students' case. Computer \& Education, $35 ; 65-80$.

21. Willoughby, T. (2008). A short-term longitudinal study of Internet and computer game use by adolescent boys and girls: Prevalence, frequency of use, and psychosocial predictors. Developmental Psychology, 44(1); 195- 204.

22. Cao, F., Su, L., Liu, T. \& Gao, X. (2007). The relationship between impulsivity and internet addiction in a sample of Chinese adolescents. European psychiatry: The Journal of the Association of European Psychiatrists, 22(7); 466- 471.

23. Caplan, S.E. (2002). Problematic internet use and psychosocial well-being: Development of a theory-based cognitive behavioral measurement instrument. Computers in Human Behavior, 18(5); 553- 575.

24. Kang, S. (2007). Disembodiment in online social interaction: impact of online chat on social support and psychosocial well-being. CyberPsychology \& Behavior, 10(3); 475- 477.

25. Kraut, R., Paterson, M., Lundmark, V., Kiesler, S., Mukophadhyay, T. \& Scherlis, W. (1998). Internet paradox: A social technology that reduces social involvement and psychological well-being? American Psychologist, 53 (9) ; 1017-1031. 
26. Sang, L., Whang, M., Lee, S. \& Chang, G.(2003). Internet over-users' psychological profiles: A behavior sampling analysis on internet addiction. CyberPsychology \& Behavior, 6(2); 143- 150.

27. Shapiro, J. S. (1999). Loneliness: Paradox or artifact? American Psychologist, 54(9); 782- 783.

28. Iso-Ahola, S. E., \& Crowley, E. D. (1991) “Adolescent substance abuse and leisure boredom." Journal of Leisure Research, 23(3), 260-271.

29. Iso-Ahola, S. E., \& Weissinger, E. (1990) "Perceptions of boredom in leisure: Conceptualization, reliability and validity of the leisure boredom scale." Journal of Leisure Research, 22(1), 1-17.

30. Leung, L.(2007). Leisure Boredom, Sensation Seeking, Self-esteem, Addiction Symptoms and Patterns of Mobile Phone Use. Center for Communicaion Research School of Journalism \& Communication The Chinese University of Hong Kong, 1-36.

31. Kubey, R.W., Lavin, M. J., \& Barrows, J. R. (2001). Internet use and collegiate academic performance decrements: early findings. Journal of Communication, $51,366-382$.

32. Yang, S. C., \& Tung, C. J. (2007). Comparison of internet addicts and non-addicts in Taiwanese high school. Computers in Human Behavior, 23(1), 79-96.

33. Morahan-Martin, J.M. \& Schumacher, P. (2000). Incidence and correlates of pathological internet use among college students. Computers in Human Behavior, 16; 13- 29.

34. Huang, R. L., Lu, Z., Liu, J. J., You, Y. M., Pan, Z. Q., Wei, Z., et al. (2009). Features and predictors of problematic internet use in Chinese college students.

35. Behaviour \& Information Technology, 28, 485-490.

36. Stavropoulos V., Alexandraki K., Motti-Stefanidi F. (2013). Recognizing internet addiction: Prevalance and relationship to academiz achievement in adolescents enrolled in urban and rural Greek high schools. Journal of Adolescence, 36, 565576. (Ministry of Education \& Human Resources, 2006). Won-han yaz

37. Hofferth, S. L., \& Sandberg, J. F. (2001). How American children spend their time. Journal of Marriage and Family, 63, 295-308.

38. Stattin, H., Kerr, M., Mahoney, J., Persson, A., \& Magnusson, D.(2005). Explaining why a leisure context is bad for some girls and not for others. In J. L. Mahoney, R. W. Larson, \& J. S. Eccles (Eds.), Organized activities as context of development: Extracurricular activities, after-school and community programs (pp. 211-234). Mahwah, NJ: Lawrence Erlbaum. 
39. Gross, E. F. (2004). Adolescent Internet use: What we expect, what teens report. Applied Development Psychology, 25, 633-649.

40. Pedersen, S., \& Seidman, E. (2005). Contexts and correlates of out-of-school activity participation among low-urban adolescents. In J. L. Mahoney, R. W. Larson, \& J. S. Eccles (Eds.), Organized activities as context of development: Extracurricular activities, after-school and community programs (pp. 85-109). Mahwah, NJ: Lawrence Erlbaum.

41. Won, S.J., \& Han, S. (2010). Out-of-School Activities and Achievement Among Middle School Students in the U. S. and South Korea. Journal of Advanced Academics, 21(4), 628-661.

42. TÜİK (TSI: Turkish Statistics Ins.). Hane Halkı Bilişim Teknolojileri Kullanım Araştırması, Erişim tarihi: 15.08.2015 http://www.tuik.gov.tr/, 2014.

43. Dinç, M. (2012). Türkiye Dijital Oyunlar Federasyonu, Erişim tarihi: 01.04.2016 https://www.tbmm.gov.tr/arastirma komisyonlari/bilisim internet/docs/sunuml ar/turkiye dijital oyunlar federasyonu.pdf

44. Turkey Statistical Institute (TSI), 2014-2015 Time Survey. http://www.tuik.gov.tr/PreHaberBultenleri.do?id=18627.

45. Karaküçük, S. (2008). Rekreasyon. Ankara: Gazi Kitabevi.

46. Gill, D.L. \& Bedini, L.A. (2010) Health, wellness, quality of life: Accent the positive. In L.Payne, B. Ainsworth, \& G. Godbey (Eds.), Leisure, health, and wellness: Making the connections (11-20). State College, P.A.: Venture Publishing.

47. Keller, C., Fleury, J., \& Rogers, C. (2010) Leisure and social health. In L. Payne, B. Ainsworth, \& G. Godbey (Eds.), Leisure, health, and wellness: Making connections (100-107). State College, P.A.: Venture Publishing.

48. Dupuis, S.L. (2008) Leisure and ageing well. World Leisure, 50(2), 91-107 
Creative Commons licensing terms

Authors will retain the copyright of their published articles agreeing that a Creative Commons Attribution 4.0 International License (CC BY 4.0) terms will be applied to their work. Under the terms of this license, no permission is required from the author(s) or publisher for members of the community to copy, distribute, transmit or adapt the article content, providing a proper, prominent and unambiguous attribution to the authors in a manner that makes clear that the materials are being reused under permission of a Creative Commons License. Views, opinions and conclusions expressed in this research article are views, opinions and conclusions of the author(s). Open Access Publishing Group and European Journal of Physical Education and Sport Science shall not be responsible or answerable for any loss, damage or liability caused in relation to/arising out of conflict of interests, copyright violations and inappropriate or inaccurate use of any kind content related or integrated on the research work. All the published works are meeting the Open Access Publishing requirements and can be freely accessed, shared, modified, distributed and used in educational, commercial and noncommercial purposes under a Creative Commons Attribution 4.0 International License (CC BY 4.0). 